University of New Orleans

ScholarWorks@UNO

Fall 1993

\title{
Ezra Pound's Encounter with Wang Wei: Toward the 'Ideogrammic Method' of The Cantos
}

Zhaoming Qian

University of New Orleans, zqian@uno.edu

Follow this and additional works at: https://scholarworks.uno.edu/engl_facpubs

Part of the Literature in English, North America Commons

\section{Recommended Citation}

Qian, Zhaoming. "Ezra Pound's Encounter with Wang Wei: Toward the 'Ideogrammic Method' of The Cantos." Twentieth Century Literature: A Scholarly and Critical Journal 39.3 (1993): 266-282.

This Article is brought to you for free and open access by the Department of English and Foreign Languages at ScholarWorks@UNO. It has been accepted for inclusion in English Faculty Publications by an authorized administrator of ScholarWorks@UNO. For more information, please contact scholarworks@uno.edu. 


\section{Twentieth-}

\section{Century}

\section{Literature}

UI

Ezra Pound's Encounter with Wang Wei: Toward the "Ideogrammic Method" of The Cantos Author(s): Zhaoming Qian

Source: Twentieth Century Literature, Vol. 39, No. 3 (Autumn, 1993), pp. 266-282

Published by: Hofstra University

Stable URL: http://www.jstor.org/stable/441687

Accessed: 02/05/2011 16:06

Your use of the JSTOR archive indicates your acceptance of JSTOR's Terms and Conditions of Use, available at http://www.jstor.org/page/info/about/policies/terms.jsp. JSTOR's Terms and Conditions of Use provides, in part, that unless you have obtained prior permission, you may not download an entire issue of a journal or multiple copies of articles, and you may use content in the JSTOR archive only for your personal, non-commercial use.

Please contact the publisher regarding any further use of this work. Publisher contact information may be obtained at http://www.jstor.org/action/showPublisher?publisherCode=hofstra.

Each copy of any part of a JSTOR transmission must contain the same copyright notice that appears on the screen or printed page of such transmission.

JSTOR is a not-for-profit service that helps scholars, researchers, and students discover, use, and build upon a wide range of content in a trusted digital archive. We use information technology and tools to increase productivity and facilitate new forms of scholarship. For more information about JSTOR, please contact support@jstor.org. 


\title{
Ezra Pound's Encounter with Wang Wei: Toward the "Ideogrammic Method" of The Cantos
}

\author{
ZHAOMING QIAN
}

In Ezra Pound Among the Poets, edited by George Bornstein, Li Po is recognized as one of Pound's major influences. Pound himself acknowledged his debt to the Chinese poet by introducing Cathay (1915) as a book "for the most part from the Chinese of Rihaku [Li Po]" $(P$ 130). Li Po, however, was not the only T'ang poet who influenced Pound in his early career. New evidence shows that after the publication of Cathay Pound continued to explore Chinese poetry through the Fenollosa Notebooks, ${ }^{1}$ and that the poet who claimed a strong appeal for him during this period, the period that witnessed Pound's extraordinary experiments in pursuit of forms for The Cantos, was $\mathrm{Li}$ Po's contemporary Wang Wei (699-759), or Omakitsu, as he is called by Fenollosa.

I take for proof of this neglected encounter Pound's own statements made on various occasions between mid-1916 and early 1919. The first of such statements is to be found in Pound's letter to Iris Barry, dated 24 August 1916: "I have spent the day with Wang Wei, eighth century Jules Laforgue Chinois" ( $L$ 144). With it we can determine the date when Pound began his serious dialogue with Wang Wei. In addition, we are enabled to see why Pound should at this point show such enthusiasm for the T'ang painter-poet: he saw in him a modern sensibility and a likeness to the French symbolist Jules Laforgue. Pauline Yu contends that "Wang Wei's work is a fulfillment of several key Symbolist aims" (Poetry 22). To illustrate this, she enumerates as many as four poetic notions shared by the T'ang poet 
and the symbolists. ${ }^{2}$ Thus Pound's comparison of Wang Wei to Laforgue confirms his critical perceptivity. In Wang Wei he apparently discovered the possibility of further modernizing his style by combining the French and Chinese influences.

Pound made a second statement about Wang Wei in his letter to Kate Buss, dated 4 January 1917. There he again emphasizes Wang Wei's modernity and his resemblance to the French Symbolists: "Omakitsu is the real modern-even Parisian-of VIII cent. China-" ( $L$ 154). This seems to indicate that Pound was continuing his study of Wang Wei in early 1917 (when he was almost ready to publish "Three Cantos"). Nevertheless, it was not until November 1918 (when he was rewriting Ur-Canto 4) that he brought out a short version of Wang Wei's poem in The Little Review:

\section{Dawn on the Mountain}

Peach flowers turn the dew crimson, Green willows melt in the mist, The servant will not sweep up the fallen petals, And the nightingales

Persist in their singing.

\section{Omakitsu}

Apparently Pound was not satisfied with his translation, for he remarked in an essay on Remy de Gourmont (another French Symbolist he admired), in the February 1919 issue of the same magazine: "I do not think it possible to overemphasize Gourmont's sense of beauty. The mist clings to the lacquer. His spirit was the spirit of Omakitsu; his pays natal was near to the peach-blossom-fountain of the untranslatable poem" ( $L E$ 343). Here Pound is of course comparing de Gourmont's sense of beauty to that of Wang Wei. "The mist clings to the lacquer" is an image from another section of "Dawn on the Mountain," which, in Pound's view, vividly sums up de Gourmont's-and perhaps also Laforgue's and the Prufrock Eliot's-sensibility.

Wang Wei's spirit indeed entered Pound's Ur-Cantos along with other influences of the period. In a fragment among his early drafts for Canto 4 Pound laments for his lost adolescence, using Wang Wei's sensual image as an analogy:

When you find that feminine contact has no longer the richness of Omakitsu's verses,

Know then, o man, that the Cytherean has turned from you, fugges! 
When the smoke no longer

hangs

clings upon the lacquer,

When the night air no longer clings

to your cuticle,

When the air has in it no mystery about her,

Know then that the days of your adolence [sic] are ended

fugaces, fugges, fugus

(Qtd. in Froula 103)

Christine Froula in her study of the genesis of Canto 4 takes pains to show how Pound created the "seven enigmatic lines [that] follow the wind poem"- "Smoke hangs on the stream,/ The peach-trees shed bright leaves in the water, / Sound drifts in the evening haze, / The bark scrapes at the ford, / Gilt rafters above black water, / Three steps in an open field, / Gray stone-posts leading . . ." $(C$ 16)-by fusing the "smoke" image with other images from Wang Wei's poetry. According to her the other images in the passage- "the stream," "The peach-trees," "The bark," "the ford," "an open field," etc. - are taken from Fenollosa's version of Wang Wei's poem "Peach Source Song" (40-41), and her assertion is certainly correct. Wang Wei's "Peach Source Song" is known in Chinese literary history as an admirable effort by the poet at the age of nineteen to recreate his fifth-century precursor T'ao Ch'ien's prose narrative "Peach-blossom Fountain." In T'ao Ch'ien's original work the narrator recounts how a fisherman lost his way among a grove of peach trees and found "a new world of level country, of fine houses, of rich fields, of fine pools, and of luxuriance of mulberry and bamboo." He was told that the ancestors of these people, some five hundred years before, had taken refuge to escape tyranny and war and that "they had remained, cut off completely from the rest of the human race" (Giles 130-31). Pound, who had read H. A. Giles's version of T'ao Ch'ien's allegory, must have recognized the literary relation between the two equally brilliant works: hence his reference to Wang Wei's poem using T'ao Ch'ien's original image ("the peachblossom-fountain of the untranslatable poem”) in his 1919 article.

Pound was introduced to the Chinese painter-poet much earlier than the summer of 1916. Indeed, he may have already heard about Wang Wei in 1909 from his friend Laurence Binyon, organizer of the 
Far Eastern art works at the British Museum. ${ }^{3}$ Moreover, as a frequenter of the British Museum he may have contemplated in its Gallery of Prints and Drawings two famous Chinese landscape paintings, one attributed to Wang Wei and one ("Landscape of the Wang Chuan") by the Sung painter Chao Meng-fu after Wang Wei. ${ }^{4}$ In Painting in the Far East (1908) Binyon describes Wang Wei as the "founder of the southern school" of Chinese landscape painting, who was "even more famous for his poetry than for his painting." "Of Wang Wei," Binyon notes, "it was said that his poems were pictures, and his pictures poems" (74). Even if Pound hadn't read Painting in the Far East (which is unlikely), he would have gotten the information all the same from Binyon when viewing the above-mentioned paintings.

Pound could also have learned something about Wang Wei from Fenollosa's Epochs of Chinese and Japanese Art, compiled by his widow, Mary McNeil Fenollosa (which he probably read shortly before his meeting with Mrs. Fenollosa in the fall of 1913). There Fenollosa not only offers a brief account of Wang Wei's achievements in art (119-20), but includes among his illustrations a reproduction of the "Famous Painting of a Waterfall, said to be an original by Omakitsu (Wang Wei)" (120).

It was not until October 1913, when Pound began studying H. A. Giles's History of Chinese Literature 5 that he got a chance to examine versions of Wang Wei's poetic work. Giles, nevertheless, seems to have a rather low opinion of Wang Wei, treating him in only a single page and offering versions of but two of his short lyrics (150).

In contrast to Giles, who ranks Wang Wei conspicuously below such T'ang poets as $\mathrm{Li} \mathrm{Po}, \mathrm{Tu} \mathrm{Fu}$, and Po Chu-i, Fenollosa, in his Notebooks, gives the T'ang painter-poet sufficient attention. In September 1896, when Fenollosa began taking Chinese poetry lessons in Japan, he concentrated on just two poets, Wang Wei and Li Po. His Notebook 7, a record of his sessions with a Mr. Hirai and a Mr. Shida, contains nine poems of Wang Wei ("Omakitsu"), which Pound numbered 1 to 9 in blue crayon when he leafed through the pages in November 1914. It was apparently due to Fenollosa's influence that Pound put Wang Wei among the top eight Chinese poets in his late 1914 list of major Chinese poets, a list showing his choice for inclusion in Cathay. ${ }^{6}$ If Pound presented only one poem by Wang Wei in Cathay (epigraph to "Four Poems of Departure"), it was because his 1914-1915 Chinese endeavor was essentially an encounter between him and Li Po, and Cathay is a book mainly devoted to "Rihaku's" work.

Pound did turn his attention to Wang Wei, though. In fact, we have 
evidence not only that he studied Wang Wei's poetry in August 1916 (and probably also in 1917 and 1918), but that he made painstaking efforts to rework Fenollosa's versions of Wang Wei between 1916 and 1918. As Froula has demonstrated, Pound worked on \# 2 of Fenollosa Notebook 7, a version of Wang Wei's "Peach Source Song," in 1916 or 1917, and produced a fragmented passage for Canto 4 (40-41). The "seven enigmatic lines" of Canto 4 ("Smoke hangs on the stream / The peach-trees shed bright leaves in the water ... "), while alluding to T'ao Ch'ien's ideal land, the "Peach-blossom Fountain," have actually conflated images from two of Wang Wei's poems in Fenollosa Notebook 7-\# 2 "Peach Source Song" and \# 5 "Farm Field Pleasure" ("Dawn on the Mountain"). ${ }^{7}$ The effort is reminiscent of Pound's earlier conflation of two separate poems of Li Po in Cathay's "The River Song” (Kenner 204). It is also indicative of the evolution of Pound's "ideogrammic method" for The Cantos, a method characterized by concrete and fragmentary presentations.

Furthermore, in Fenollosa Notebook 15 entitled "Chinese Poetry, Notes by Pound, including translation," one will find the typescript of Pound's drafts for six of Wang Wei's poems (see Appendix). ${ }^{8}$ The sources of these drafts are easily identifiable because their numbers -3 , $4,5,6,7$, and 8 -correspond to those given to Fenollosa's versions contained in his Notebook 7. Although no date is given anywhere, we can still determine that these drafts came after Cathay, because for \# 6 , the Cathay piece, Pound gives not a translation but a brief note, in which the Latin phrase "vide Cathay" betrays a date later than Cathay.

It is worth noting that in Chinese literary history Wang Wei is known not only as a painter-poet, but, more important, as a poet with strong Zen-Buddhist leanings. True, a number of other T'ang poets, such as $\mathrm{Li}$ Po and Po Chu-i, also show to varying degrees the influence of Zen-Buddhist thinking. But it is in the poetry of Wang Wei that we find the full development of a poetics based on the Zen-Buddhist conceptions of nonbeing as being, emptiness as form, and transcendence of the duality between self and world. Fenollosa, who had studied Zen-Buddhist doctrines, was obviously aware of some of the religious implications in Wang Wei's poems. To his word-for-word translation of the seventh poem "Painful Heat," for instance, he has appended such a note: "There must be some Buddhist/Zen conception here, not nearly Confucian. Possibly derived from Roshin [Lao Tzu]". ${ }^{9}$ The piece turns out to be one of Wang Wei's best-known Buddhist poems. Pauline Yu in discussing Wang Wei's religious dimension uses this same piece as an example (Poetry 124). 
What might have first caught Pound's eye in these versions of Wang Wei, however, are their distinct imagist-vorticist qualities-their painterliness, their concision, their suggestivity, and their detachment. (In fact Wang Wei derived these strengths from Taoism/ZenBuddhism.) When Pound began making his modern epic, imagistvorticist works still had a strong fascination for him. In a note to his "Vorticism" article, he implied that he would like to write "a long vorticist poem" (GB 94). We have reason to believe, therefore, that he had the intention of borrowing certain imagist-vorticist colors for his Ur-Cantos as he studied Wang Wei in 1916 and 1917. (Pound obviously equates Wang Wei's Taoism/Zen-Buddhism with his imagism/vorticism.) As Reed Way Dasenbrock observes, "Vorticism and Taoism could be parallel, perhaps, only in a cosmos organized by Ezra Pound" (226). "Farm Field Pleasure," a version of Wang Wei in Fenollosa Notebook 7, \# 5, which Pound was to work and rework, shows this:

$$
\begin{gathered}
\text { Farm field pleasure } \\
1 \text { poems } \\
\text { encloses }
\end{gathered}
$$

Peach crimson also contains inn rain

$$
\text { from night }
$$

Peach blossoms are crimson, and also contain the rain that has lodged there (in the night)(in the petals)

$$
\text { also En }
$$

Willow green nearly belts spring smoke

Willow is green, and also belts in with its silhouette this spring mists

(parallelism of words of Omar [Khayyam] lines)

Flower falling house servant not yet sweep

Uguisu crying mountain guest still sleeps

$$
\text { Min }
$$

nightingale

(the person who lives here)

(another couplet of parallelism)

$$
\text { rhyme }
$$

All Chinese poems have rhyme, but their rhyming varies with different stanza.

Earlier Pound had successfully reworked several poems of nature and of scenery by Li Po; three examples that immediately come to mind are "Taking Leave of a Friend," "The City of Choan," and portions of "Exile's Letter." He had also tried his hand at translating at least one of Wang Wei's picture poems (epigraph to "Four Poems of Departure"). When he set his eyes on the above notes in August 1916, he couldn't 
have failed to be stricken by a similar beauty and simplicity. In fact, he probably immediately went to great labor. The effort is evidenced by a draft in his hand that I have unearthed among Pound's and Fenollosa's notes for the Chinese written character and the typed version in Notebook 15, which I have referred to earlier.

Pound's first draft for Wang Wei's "Farm Field Pleasure" is penciled on the verso of a typed sheet cut in two, in Fenollosa Notebook 28. It is in fact a crib:

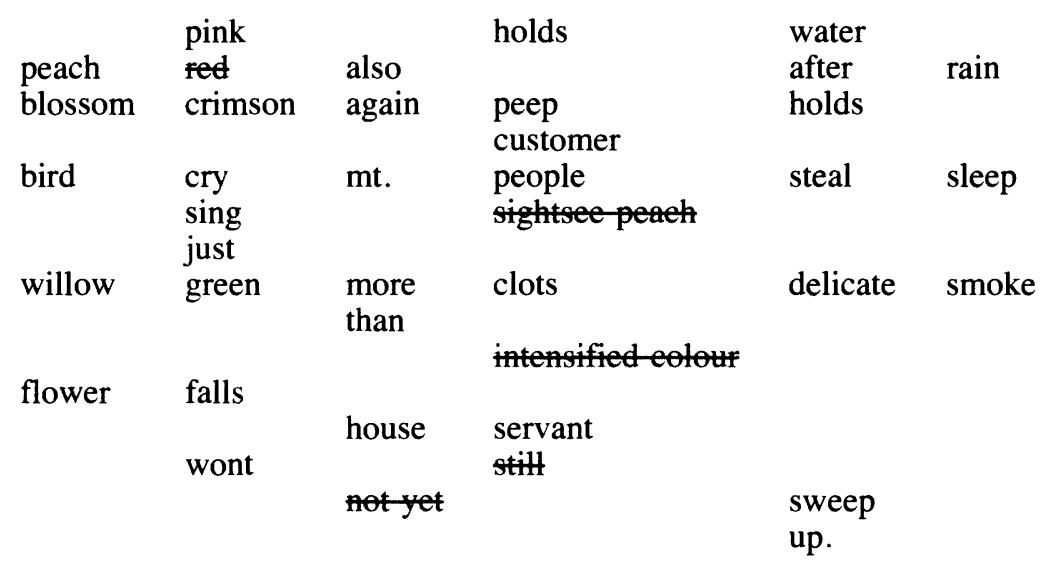

By then Pound had studied Fenollosa's unfinished essay on "The Chinese Written Character as a Medium for Poetry," 9 and, moreover, he was learning Chinese characters from his Morrison Chinese dictionary and Dorothy Shakespear's Chinese language handbook. ${ }^{10} \mathrm{He}$ was therefore able to gloss two words - "peach" and "rain" in the first line-with Chinese characters, which turn out to be the characters Wang Wei uses in the poem. Also, he was able to figure out from Fenollosa's crib that the original poem was a quatrain of six characters. His first draft is precisely an attempt to match each character in the original poem with a single English word. For certain words, such as Fenollosa's "belts" and "crying," he offers alternatives that prove to be closer equivalents to the corresponding Chinese characters. As for the line sequence, Pound cannot resist rearranging it. Thus Wang Wei's second line becomes the third, fourth line becomes the second, and third line becomes the last.

Probably during the same week (in late August 1916) Pound typed out drafts for no less than six of Wang Wei's poems. \# 5 is "Farm Field Pleasure," for which he first produced the above crib:

Peach flowers hold up the dew that shows crimson 
The green willows belt in the smoke-mist, making lines in its denseness.

Servant has not swept up the fallen petals,

The guest of this mountain, sleeps through the nightingales noise.

Here Pound is obviously trying to imitate Wang Wei's unique sense of color and form. He has restored Wang Wei's line order. And by doing so he triumphs in recapturing the contrast and parallelism that are in the original. His rendering of the last line is excellent, for it has successfully brought out the speaker's passive attitude. His translation of the first couplet, however, is not as satisfactory, for in order to achieve clarity he has destroyed Wang Wei's special charm, which resides chiefly in his concision and allusiveness.

Pound evidently became dissatisfied with his typed draft version when he returned to the poem in 1917 or 1918, for he has left subsequent penciled revisions and deletions in the draft. (He has substituted "turn the dew crimson" for "hold up the dew that shows crimson" in the first line, and deleted "smoke" and "making lines in its denseness" in the second line.) And on the verso of the previous typed leaf, one will notice yet another draft in his hand for Wang Wei's elusive quatrain:

Peach flowers turn the dew crimson,

Green willows belt in the mist,

The servant will not sweep up the fallen petals,

Our guest is not yet up, the nightingales persist in their singing.

A comparison with the published text of "Dawn on the Mountain" reveals that this is the draft closest to Pound's final product. But before submission, he apparently made one final effort to improve the concluding line. Thus, "Our guest is not yet up,/ the nightingales persist/in their singing" is shortened to "And the nightingales/ Persisting in their singing." It seems that Pound toiled to preserve everything essential, but every time he gained something he lost something else. In the first couplet, for instance, Pound brings across Wang Wei's visual clarity (his color contrast in particular) along with his formal terseness, but he has no way to recapture his simultaneity and mutual reflexiveness. (Chinese syntax allows agents to act as recipients as well, and vice versa. Thus in the first line, "peach blossoms" at once 
turn the "dew" pink and are turned glossy by the "dew.") And in the concluding line he has difficulty in highlighting both the natural and human dramas and their interrelation in succinct terms. To preserve concision, Pound is forced to sacrifice the human action ("Our guest is not yet up"), and hence the man-nature correspondence fundamental in Wang Wei's poetic world also.

Pound must have been deeply aware of his inadequacy in translating Wang Wei, for he never reprinted "Dawn on the Mountain." Moreover, upon referring to Wang Wei in the 1919 essay on de Gourmont, as we have seen, he calls his work "untranslatable." Wang Wei is indeed difficult to translate. Yu is right when she attributes the difficulty to the profound philosophy that underlies his poetry: "His poems possess a surface simplicity. . . . Yet paradoxically, on second glance, his works reveal disturbingly elusive philosophical underpinnings, grounded in Buddhist metaphysics" ("Wang Wei" 219).

Pound's failure to reproduce Wang Wei's whole art, however, has been potent, generative, ironically influential. First, he was exposed to a poetics firmly based on the non-dualistic notions of Taoism/ZenBuddhism. Though Pound may not have been able to grasp Wang Wei's Taoist/Zen-Buddhist philosophy, he was by that point both intuitively and conceptually conditioned to appreciate the T'ang poet's Taoist/Zen-Buddhist art. In Yu's description, this art perfected in Wang Wei's hand is characterized by "its concentrated vision and form; its precise yet evocative imagery; its preference for the concise and concrete as opposed to the discursive and abstract; its mode of presentation which places as much value, if not more, on what is implied as on what is stated directly" (Reading 187). Apparently these traits corresponded precisely to Pound's imagist/vorticist doctrine. By imitating Wang Wei he crystallized a critical insight that enabled him to expand subject and method.

Furthermore, Pound's encounter with Wang Wei began at the moment when he was composing and recomposing Ur-Cantos 1-3 ("Three Cantos"), and it continued through the years in which he became increasingly disenchanted with the uncertain manner with which he opened his modern epic. Ronald Bush has examined the influence of James, de Gourmont, Laforgue, Eliot, and Joyce on Pound's refashioned style for the Ur-Cantos of 1917-1919. To these we must add the art of Wang Wei that contributed to the poetic breakthrough Pound made during this period. Bush is undoubtedly correct in emphasizing the dominant impact of de Gourmont, who 
directed Pound to unify his long poem's "rag-bag" of subject matter by "the inflections of a single sensibility" (159). However, it was through comparing him with Wang Wei ("His spirit was the spirit of Omakitsu") that Pound rediscovered de Gourmont's true value, and it was by drawing on Wang Wei's imagery ("The mist clings to the lacquer") that he found the most precise and the most vivid terms to redefine de Gourmont's sensibility. Moreover, in his attempt to imitate de Gourmont in the Ur-Cantos, Pound began by imitating Wang Wei, whose art he considered an equivalent of the French symbolist's. Thus, in Ur-Canto 4 (now Canto 4), which marks Pound's turning away "from the uncertain Browningesque pastiche of 'Three Cantos' to the creation of a modern style" (Froula 5), we notice that the force which holds together his "rag-bag" of subject matter is a sensibility borrowed from Wang Wei.

In the Gourmontian context provided by Bush we can see clearly that the "Smoke-peach-trees" passage of Canto 4 is intended "precisely to display the complex subjectivity of a mind" (202). As has been demonstrated previously, the sensory images of the passage are culled from two versions of Wang Wei's poems; "Peach Source Song" communicates a youthful yearning for T'ao Ch'ien's imaginary realm of the "Peach-blossom Fountain," where men live in abundance and in peace with nature and environment, and "Farm Field Pleasure" celebrates the tranquil life of a Taoist/Zen-Buddhist recluse. Pound has made no attempt to follow the original designs of Wang Wei's poems. (In fact, I believe that he was rather relying on reminiscence sustained from reworking versions of Wang Wei to compose these lines.) Yet, by conflating key elements-sensual images and a serene manner that unmistakably bear the T'ang poet's imprint - from the two lyrics, he has miraculously reproduced the single, deep, and unified emotion that is depicted in "Peach Source Song" and "Farm Field Pleasure."

The "seven enigmatic lines" of Canto 4 are thus a beautiful imitation of a sensibility. Behind "Smoke hangs on the stream, / The peach-trees shed bright leaves in the water,/Sound drifts in the evening haze ..." stands unquestionably a mind, an intellect like Wang Wei's, that expresses serenity and leisure, peace and harmony with nature. It is important to note that in this concrete and fragmentary depiction of a single sentiment Pound saw a method, a force capable of stitching together his "rag-bag" of subject matter. He did this by allowing the sensibility of the "Smoke-peach-trees" passage to underlie the different episodes of the poem. Thus the "Palace in smoky light" scene that opens Canto 4 is intended to be sustained in the reader's 
mind until it is juxtaposed with the "Smoke-peach-trees" passage. The echo of the "smoke" image is to set up a contrast that releases a complex of emotions involving visions of Trojan glory and wreckage repeated in modern European history. The Ityn / Cabestan episode with lines such as "And she went toward the window,/the slim white stone bar / Making a double arch" is meant to be set side by side with the final two of the "seven enigmatic lines"-"Three steps in an open field, / Gray stone-posts leading ..." The Buddhist ideal suggested is to strike a remarkable balance with the speaker's disgust at past and present impurity.

Hugh Kenner is among the first critics to have an insight into Pound's early intention of building his long epic around certain concrete forms of Eastern spirits. For him one such form that ideally fulfils Pound's purpose is the sacred twin pines of Takasago and Sumiyoshi (529). Needless to say, the Noh image first referred to in Canto 4 evokes precisely the same Taoist/Zen-Buddhist consciousness of sincerity, peace, and eternal bond as lies behind the "Smoke-peachtrees" scene of Wang Wei. So does the vision of Père Henri Jacques conversing with the Sennin on Rokku. So does the "wind poem" that precedes the "seven enigmatic lines." True, the "wind poem" opens with So-Gyoku's (or rather Sung Yu's) un-Taoist-like statement- "This wind, sire, is the king's wind." But the poet's flattery is after all quoted only to be refuted by a more eloquent voice-"No wind is the king's wind"-which indubitably concurs with the poem's single unifying sentiment.

Significantly, the Taoist voice of Canto 4 rings again seventy cantos later in the first Pisan Canto: "The wind is part of the process / The rain is part of the process" $(449)^{11}$ just as the Zen-Buddhist images of Wang Wei recur many more times in the modern epic. Kenner is certainly right in maintaining that in Pound's long poem "Wars, ruins, destructions - a crumbling wall in Mantua, smoke over Troy-these are never far out of mind" (416). But to this statement we may add: superimposed upon the "evil things" of the world is an "eternal consciousness" often expressed by recurrent paradisiacal images from Eastern sources. This pattern is followed most visibly in Canto 16, where the speaker journeying from hell to Mount Purgatory has alternate visions of a pastoral region with Wang Wei's "calm field," "quiet air," and "fountain" (69), and of the Franco-Prussian War and the First World War. Wang Wei's "Smoke-peach-trees" scene, one must perceive, changes to the apricot blossoms in Canto 13, the Seven Lakes in Canto 49, and Taishan in the Pisan Cantos. In Canto 84, the last Pisan Canto, nonetheless, this Taoist/Zen-Buddhist landscape sticking 
in Pound's mind for more than thirty years finally returns in its prototypical form:

where one walks into Spagna

that T'ao Ch'ien heard the old Dynasty's music as it might be at the Peach-blossom Fountain where are smooth lawns with the clear stream between them, silver, dividing

So far, we haven't given a name to the style of concrete presentation, conflation, ellipsis, discontinuity, allusion, and juxtaposition that characterizes Pound's refashioned cantos from Ur-Canto 4 onward. The procedure, according to Bush, remained nameless until 1927, when Pound began to speak of it as the "ideogrammic method" (10). We have reason to believe now that the seed of this method was nourished between 1917 and 1919 through Pound's study of Fenollosa's essay on Chinese characters and the work of Wang Wei, de Gourmont, Laforgue, Eliot, and Joyce. ${ }^{12}$

In discussing Pound's development of the "ideogrammic method" critics tend to pay more attention to the source that provided its name and aesthetic framework than to the factors that contributed the substance. The fact is that Pound was in search of a theory promoting the kind of poetry he was constructing, and Fenollosa's essay appeared to serve the purpose ideally. Yes, we must understand that the essay's admiration for the alleged pictorial qualities of the Chinese written language is absurd and misleading. But, as Bush has observed, Pound's interest was in "the spirit of Fenollosa's remarks about oriental logic," and not in "their letter" (10). A proof for this, he points out, exists in one of Pound's 1919 notes to the essay: "These precautions should be broadly conceived. It is not so much their letter, as the underlying feeling of objectification and activity, that matters" (qtd. 179). So, for the Pound of 1919 Fenollosa's big essay was valuable principally because it offered him a way to account for the spirit underlying the poetry he was incorporating into his modern epic. In other words, in Pound's effort of 1917-1919 to modernize the style of his Ur-Cantos, Fenollosa's essay on Chinese characters served at most as a postulate that supported his spiritual sentiment, whereas the examples of Wang Wei, de Gourmont, Laforgue, Lewis, Eliot, Joyce, Cubist collage, etc., combined to supply the material and technique for the mode of presentation that gradually grew to be known as the "ideogrammic method."

To sum up, we see that what characterized Pound's transitional phase - the phase that witnessed the appearances of "Homage to Sextus 
Propertius" and his first refashioned Ur-Cantos-was his conscious effort to link past with present, and Eastern culture with Western culture. If prior to 1917 he had in the main submitted himself to one influence at a time, starting from 1917 he began to consciously bring all the influences together. Pound's modernist style for The Cantos is thus a style of superposition, superposing not just imagery upon emotion, but Wang Wei upon de Gourmont/Laforgue, Kung upon Malatesta/ Adams - in short, past upon present and Eastern culture upon Western culture. As a literary figure clinging to Pound's mind for so long and contributing significantly to his modernist style, Wang Wei has a firm claim to our attention.

\section{APPENDIX}

A typescript of Pound's Drafts for Six Poems of Wang Wei in Fenollosa Notebook 15.

Copyright (C) 1993 by the Trustees of the Ezra Pound Literary Property Trust. Reprinted by courtesy of the Beinecke Rare Book and Manuscript Library, Yale University.

Omakitsu

Poor dwelling near valley mouth High tree belts rough village

Palanquin twists about stone road

Who comes to gate of mountain abode?

Freezing bay glues fishing boat

Hunters fire burns in cold field

Only white cloud overhead

Temple bell and monkey cry rarely heard.

4

Sitting in mystic bamboo grove, back unseen

Press stops of long whistle

Deep forest unpierced by man

Moon and I face each other.

Peach flowers turn the dew crimson green willows belt in the mist,

The servant will not swept [sic] up the fallen petals,

The guest of this mountain, sleeps through the nightingales noise. 
[Written down right margin in longhand] The guest is not yet up. The nightingales are still crying.

6

"When you come to the gates of Go." vide Cathay.

Someone said to Gengi when he was going to Arisei as messenger, still sung at parting in Japan.

Red sun fills heaven and earth

Fiery clouds are heaped up like mountain on mountain Grasses and trees are parched, twisted,

River and marsh are baked dry.

The light gauze weighs heavy upon me

The thick tree shade is worn thin,

Bamboo mats are to [sic] hot to touch

We must wash our summer net dress over and over

I send my thought out from the world

I give it space in the open

Long wind from 10,000 miles

a sea wind clears off the dust.

Then I reflect that the boredom comes from body

I known [sic] that I am not fully enlightened

What pleasere [sic] have in detachment

like that of going into the gates drenched with dew

8

The mountain is empty and empty

Dark trees crowd thicker and thicker

Pompous officers stuff up the court,

How are you in your vacant valley?

Letters little harmony, think deep.

you walk alone, breaking and [sic] unknown path.

(tree-circling)

Rest glad on a stone, drink of the shadweed free

flowing stream

Your gate is of pine boughs, your house a grass thatch reed thatch

You feed your cocks in the clouds

Have you lugged that calf up in your arms?

God makes your Natsume (dates) like melons,

Does a tame tiger yet sell your apricots, and get in your autumn corn.

(Story of sages tame tiger who used to keep stall 
for his master. People took from $\mathbf{x x x x} \operatorname{xxxx} \operatorname{xxxxx}$

I am ashamed of my stupidity, interrupting your meditation

I dislike being so old, so dependent on a salary that I have to get through six rows of officers pawed over by sixteen officials.

I promise you I will give up my office and follow you.

What need of asking old Sen, for a judgement in augury

2.d ode on same topic.

(go toward)

The mountain dweller wishes to return to the mountain

The clock cloud goes blacker spilling out torrents of rain

The water ripples out from the stream bed flushing the green dark grass (bends it aslant with the current

A white heron fall like white paper

This way is too rough, do not go. (????)

A thousand ducks gather into one cloud You can not tell the sky from the mountain The mist is interwoven with darkness

The monkeys themselves can not see.

Evening sun strikes over the mountain

The far eastern village stands out as if near the fields in betwwen [sic] are all hazy and invisible

I am sad at your going. full of envy, my friend.

\section{NOTES}

1 The "Fenollosa Notebooks," at the Beinecke Rare Book and Manuscript Library at Yale University, consist of 82 folders. A number of them contain sheaves of leaves rather than notebooks; some contain material contributed by Pound rather than Fenollosa.

All previously unpublished material by Ezra Pound and Ernest Fenollosa, Copyright (C) 1993 by the Trustees of the Ezra Pound Literary Property Trust, is used by permission of New Directions Publishing Corporation, agents for the trustees, and by courtesy of the Collection of American Literature, Beinecke Rare Book and Manuscript Library, Yale University. 
${ }^{2}$ According to Yu, Wang Wei and symbolists share: (1) the notion of "a non-representational, suggestive poetry"; (2) "the preference for embodiment over assertion, the intuitively apprehended image over logically structured, propositional discourse"; (3) the "reliance on the image or symbol to convey meaning impersonally, rather than direct description or personal expression"; and (4) the notion of "poetry as the manifestation of a unitary principle" (22-28).

${ }^{3}$ Early in 1909 Laurence Binyon invited Pound to a lecture he gave on "Oriental and European Art" (Stock 61). In the lecture Binyon may have touched upon Wang Wei's contribution to Chinese landscape painting as he had done in his work of the previous year, Painting in the Far East.

${ }^{4}$ The two paintings are catalogued in Binyon's Guide to an Exhibition of Chinese and Japanese Paintings in the Print and Drawing Gallery (1910). For an illustration of Chao Meng-fu's copy of Wang Wei, see Binyon 66.

${ }^{5}$ Proofs of the date can be found in Pound's letters to Dorothy Shakespear. In a letter of 7 October 1913, Pound quotes from Giles's History (EP \& DS 267). And in a letter of 11 October 1913 he tells Dorothy that she can have "Giles' 'Hist. of Chinese Lit'" (270).

${ }^{6}$ Fenollosa Notebook 15 contains the typescript of a columnar list of names and dates prepared by Pound presumably in late 1914, in which King Wen, Confucius, Ch'u Yuan, Mei Sheng, Lady Pan, T'ao Ch'ien, Wang Wei, and Li Po are marked as top literary figures.

${ }^{7}$ In fact \# 6 of a suite of seven quatrains titled "Farm Field Pleasure." The suite is believed to have been written after Wang Wei purchased the Wang Chuan country home miles east of the T'ang capital Chang'an, where he led a double life as official and recluse in his later years.

${ }^{8}$ Pound may well have reworked all Fenollosa's versions of Wang Wei. I failed to locate his drafts for \# 1, 2, and 9 in my summer 1990 search through Fenollosa Notebook 15.

${ }^{9}$ In Fenollosa Notebook 7.

${ }^{10}$ The Chinese Language and How to Learn It: A Manual for Beginners by Sir Walter Caine Hillier (1910 ed.) (EP E DS 298n).

${ }^{11}$ Dasenbrock perceptively notes that The Pisan Cantos indicates a return to the Taoist poetic "developed at the time of Pound's first immersion in Oriental material" (226).

12 It was during the summer of 1916 that Pound wrote Iris Barry: "You should have a chance to see Fenollosa's big essay on verbs" ( $L 131)$, and again, "I have spent the day with Wang Wei" (144). In fact, Pound's effort to publish Fenollosa's essay and his experiments with Wang Wei persisted concomitantly through 1919.

\section{WORKS CITED}

Binyon, Laurence. Painting in the Far East. London: Arnold, 1908.

Bornstein, George, ed. Ezra Pound Among the Poets. Chicago: U of Chicago P, 1985.

Bush, Ronald. The Genesis of Ezra Pound's Cantos. Princeton: Princeton UP, 1976. 
Dasenbrock, Reed Way. The Literary Vorticism of Ezra Pound and Wyndham Lewis. Baltimore: Johns Hopkins UP, 1985.

Fenollosa, Ernest. Epochs of Chinese and Japanese Art. London: Heinemann, 1912. Vol. I.

Froula, Christine. To Write Paradise: Style and Error in Pound's Cantos. New Haven: Yale UP, 1984.

Giles, H.A. A History of Chinese Literature. New York: Appleton, 1901.

Kenner, Hugh. The Pound Era. Berkeley: U of California P, 1971.

Pound, Ezra. The Cantos. 11 th printing. New York: New Directions, 1989. (C) . Ezra Pound and Dorothy Shakespear: Their Letters 1909-1914. Ed. Omar Pound and A. Walton Litz. New York: New Directions, 1984. (EP \& DS) . Gaudier-Brzeska: A Memoir. 1916. New York: New Directions, 1970. (GB) The Letters: 1907-1941. Ed. D. D. Paige. New York: Haskell, 1974. (L) Literary Essays. Ed. T. S. Eliot. New York: New Directions, 1968. (LE) Personae: The Shorter Poems. Ed. Lea Baechler and A. Walton Litz. New York: New Directions, 1990. $(P)$

Stock, Noel. The Life of Ezra Pound. London: Routledge, 1970.

Yu, Pauline. The Poetry of Wang Wei: New Translations and Commentary. Bloomington: Indiana UP, 1980. The Reading of Imagery in the Chinese Poetic Tradition. Princeton: Princeton UP, 1987.

."Wang Wei: Recent Studies and Translations." Chinese Literature: Essays, Articles, Reviews 1.2 (1979): 219-40. 